\title{
Bone disease in primary hyperparathyroidism
}

\section{Doença óssea no hiperparatiroidismo primário}

Francisco Bandeira', Natalie E. Cusano ${ }^{2}$, Barbara C. Silva ${ }^{3}$, Sara Cassibba ${ }^{4}$, Clarissa Beatriz Almeida', Vanessa Caroline Costa Machado', John P. Bilezikian²
${ }^{1}$ Division of Endocrinology, Diabetes and Bone Diseases, Agamenon Magalhães Hospital, Brazilian Ministry of Health, University of Pernambuco (UPE) Medical School, Recife, PE, Brazil ${ }^{2}$ Metabolic Bone Diseases Unit, Division of Endocrinology, Department of Medicine, College of Physicians and Surgeons, Columbia University, New York, NY, United States

${ }^{3}$ Federal University of Minas Gerais (UFMG), Belo Horizonte, MG, Brazil ${ }^{4}$ Division of Endocrinology and Metabolism, Santa Croce and Carle Hospital, University of Turin, Cuneo, Italy tecture. Newer technologies, such as high-resolution peripheral quantitative computed tomography (HR-pQCT), have provided further understanding of the microstructural skeletal features in PHPT. Arq Bras Endocrinol Metab. 2014;58(5):553-61

\section{Keywords}

Hyperparathyroidism; osteitis fibrosa cystica; nephrocalcinosis

\section{RESUMO}

A doença óssea no hiperparatiroidismo primário grave é representada pela osteíte fibrosa cística (OFC). Dor óssea, deformidades esqueléticas e fraturas patológicas são achados comuns na OFC. A densidade mineral óssea está, usualmente, extremamente diminuída na OFC, mas é reversível após a cura cirúrgica. Os sinais e sintomas da doença óssea grave incluem dor óssea, fraturas patológicas e fraqueza muscular proximal com hiper-reflexia. 0 comprometimento ósseo é tipicamente caracterizado pela aparência em "sal-e-pimenta" nos ossos do crânio, erosões ósseas e reabsorção das falanges, tumores marrons e cistos. Na radiografia, observam-se desmineralização difusa e fraturas patológicas especialmente nos ossos longos das extremidades. No hiperparatiroidismo primário (HPTP) sintomático grave, as concentrações séricas de cálcio e PTH estão usualmente bem elevadas e o comprometimento renal se caracteriza pela presença de urolitíase e nefrocalcinose. Uma nova tecnologia, recentemente aprovada para uso clínico nos Estados Unidos e na Europa, torna-se provável se difundir rapidamente, pois utiliza as imagens geradas pela densitometria DXA. 0 escore trabecular ósseo (TBS), obtido por meio da análise do nível da textura cinza das imagens dos corpos vertebrais, fornece informações indiretas sobre a microarquitetura trabecular. Novos métodos, como a tomografia de alta resolução quantitativa periférica computadorizada (HRpqCT), têm proporcionado conhecimentos adicionais sobre os achados da microarquitetura esquelética no HPTP. Arq Bras Endocrinol Metab. 2014;58(5):553-61

\section{Descritores}

Hiperparatireoidismo; osteíte fibrosa cística; nefrocalcinose

Correspondence to: Francisco Bandeira Disciplina de Endocrinologia, Faculdade de Ciências Médicas, Universidade de Pernambuco Av. Rui Barbosa, 1435 52050-450 - Recife, PE, Brasil fbandeira@gmail.com

Received on Mar/26/2014 Accepted on May/26/2014 DOI: 10.1590/0004-2730000003381 


\section{SKELETAL DISEASE IN SEVERE PRIMARY HYPERPARATHYROIDISM}

B one disease in severe primary hyperparathyroidism (PHPT) is described classically as osteitis fibrosa cystica (OFC). Bone pain, skeletal deformities and pathological fractures are features of OFC (1). Bone mineral density is usually extremely low in OFC, but it is reversible after surgical cure (2).

The clinical presentation of PHPT has changed globally, with the first reports in the 1970s coming from the United States and Europe where the multichannel screening test was introduced. Most patients whose PHPT is discovered in this manner do not show overt skeletal or renal complications. In Latin America, at a time when the United States and European centers were describing a change in this clinical phenotype, most studies continued to see a very symptomatic disease. With time, however, countries such as Brazil have also seen a change in the presentation of PHPT toward the asymptomatic form (3). This change has also been reported recently in China (4). However, other Asian countries like India, Iran, Saudi Arabia and Thailand reported widespread prevalence of symptomatic disease with skeletal manifestations (3).

In a series of 124 patients from Recife, about ten years ago, $25 \%$ of patients had severe skeletal involvement and OFC (1). Similar data were found in the city of São Paulo (5). More recently, however, in a recent epidemiological study from the same institution with 4207 patients evaluated, only $6.1 \%$ had OFC (6).

The aim of this work is to review current more relevant data on bone involvement in the various forms of primary hyperparathyroidism.

\section{Clinical manifestations}

The signs and symptoms of severe bone disease include bone pain, pathologic fractures, proximal muscle weakness with hyperreflexia. Although these patients usually present with non-specific symptoms such as weakness, depression and constipation, the dominant picture occurs due to severe bone abnormalities (1). Bone involvement is typically characterized as salt-and-pepper appearance in the skull (Figure 1), bone erosions and bone resorption of the phalanges (Figure 2), brown tumors and cysts (1). The osteoclastomas are typical radiological changes of severe hyperparathyroidism, represented by OFC (7) (Figure 3).
Renal involvement is manifested by nephrolithiasis and nephrocalcinosis (3). The stones are usually small, comprised of calcium oxalate or calcium phosphate and are seen on abdominal radiographs or renal ultrasound. In the most severe cases, mineralization of renal tissue occurs (8).

Symptomatic patients may also present with neuropsychiatric symptoms, such as anxiety, depression, confusion, memory loss, irritability, difficulty in concentration, and sleep disorders (1). The prevalence of these symptoms is not known due to the lack of rigorous and systematic evaluation in most series (3).

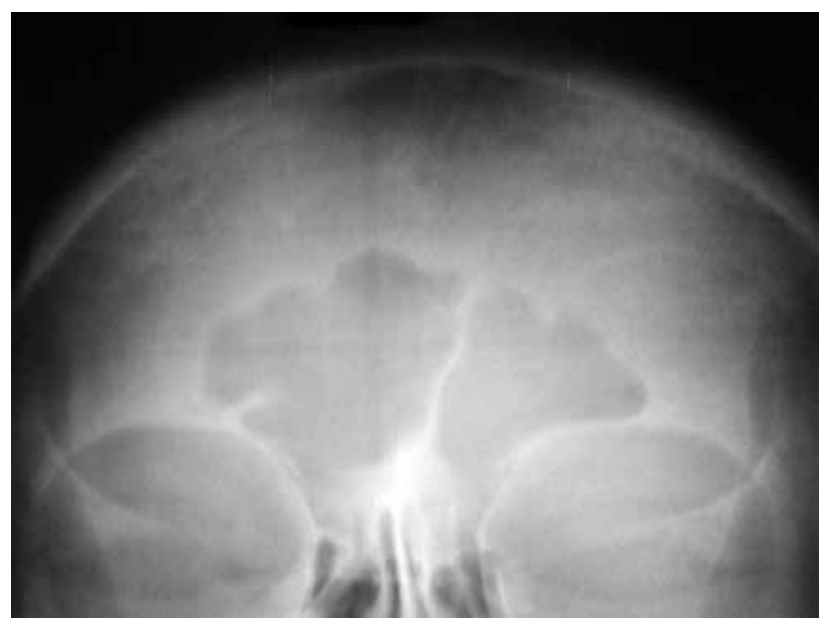

Figure 1. Plain X-Ray shown "salt-and-pepper" appearance of the skull in a 38 years old female patient OFC.

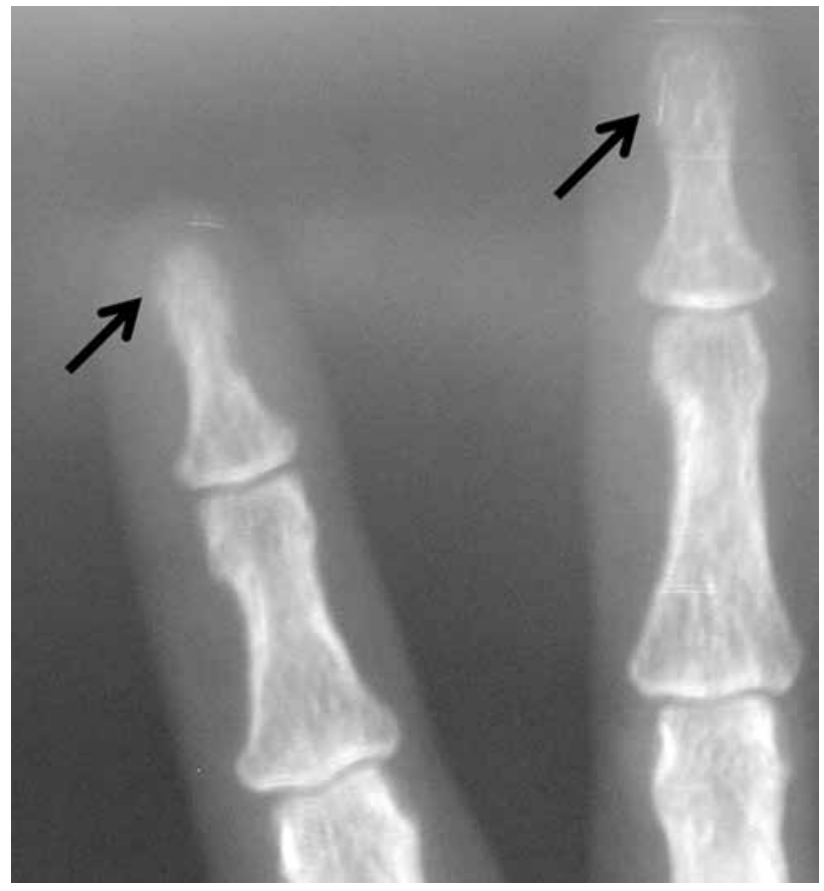

Figure 2. Subperiosteal bone erosions on phalanges of the same patient from figure 1. 


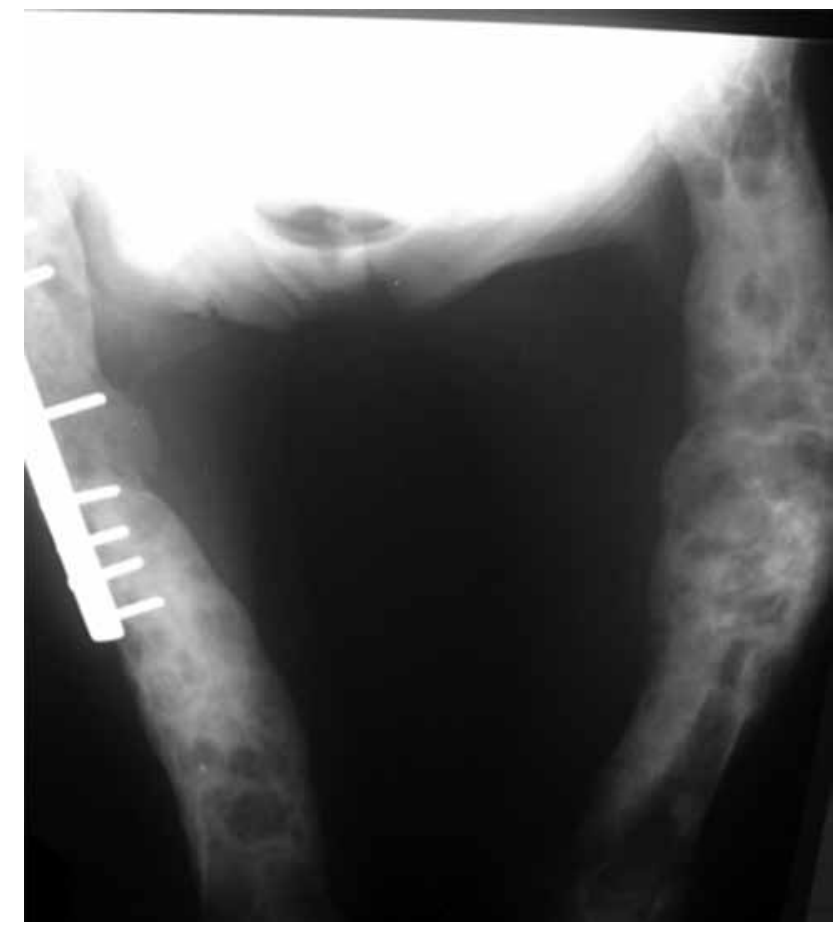

Figure 3. Fifty-seven years old with female with osteitis fibrosa cystica showing huge osteoclastomas in the femurs bilaterally.

\section{Diagnosis}

\section{Radiography}

Diffuse demineralization is observed, along with pathological fractures, particularly in the long bones of the extremities along with a salt and pepper appearance of the skull (8).

Subperiosteal bone erosions in the distal phalanges and on the lateral aspects of the middle phalanges are also seen, appearing as sclerotic or lytic lesions with irregular margins. The pelvis, long bones and shoulders are common sites to see these manifestations. The cortex of the long bones is extremely thin and almost absent in some patients (9).

\section{Ultrasound}

Ultrasonography of the kidneys and urinary tract should be obtained if the clinical history suggests nephrolithiasis. It is reasonable to considered this even in the absence of symptoms of nephrocalcinosis or nephrolithiasis (8).

\section{Bone mineral density}

Bone mineral density of the lumbar spine, hip regions (total hip and femoral neck) and distal $1 / 3$ radius should be measured in all patients. The distal $1 / 3$ ra- dius, a site of cortical bone, is particularly important to measure in PHPT because of the catabolic effects of PTH in cortical bone (10).

High-resolution peripheral computed tomography (HRpQCT) permits non-invasive assessment of cortical and trabecular microarchitecture of the distal radius and tibia. As noted below, HRpQCT has been applied recently to evaluate cortical and trabecular bone quality in $\operatorname{PHPT}(3)$.

\section{Laboratory data}

In severe, symptomatic PHPT, marked elevation of the serum calcium and PTH concentrations are common. The accurate measurement of the serum calcium should take into account the fact that $40 \%$ of circulating calcium is bound to albumin. If the serum albumin concentration is abnormal, the measured serum calcium concentration must be adjusted using the formula: $[$ corrected calcium $=$ serum calcium concentration $\mathrm{mg} / \mathrm{dL}+[0.8 \times(4$-serum albumin $)]$. The direct measurement of ionized calcium can be useful in selected situations such as extreme hyper- and hypoalbuminemia, thrombocytosis, Waldenström's macroglobulinemia and myeloma (8).

Biochemical markers of bone formation, such as osteocalcin, alkaline phosphatase (AP) or markers of bone resorption, such as deoxypyridinoline, $\mathrm{N}$-telopeptide (NTX) and C-telopeptide (CTX) are typically markedly elevated in severe PHPT. Alkaline phosphatase is well above normal in virtually all patients with OFC (7).

Renal function and serum $25 \mathrm{OHD}$, as well as 24 hour urine calcium must be evaluated. Low levels of $25(\mathrm{OH}) \mathrm{D}$ have been linked to the severity of the disease, increased bone turnover and low bone mineral density measurements (9). Table 1 shows the main differences between the various forms of hypercalcemic primary hyperparathyroidism.

\section{Localization techniques}

Among the several technologies that are useful in located the abnormal parathyroid gland, ultrasonography is inexpensive and noninvasive. Its disadvantage is in limited resolving power and in being operator dependent. Ultrasonography has a sensitivity of $88 \%$ and specificity of $94 \%$, but when combined with Tc-99-sestamibi scintigraphy with SPECT-CT it can improve to 97 and $100 \%$ respectively $(8,9,11)$. 
Table 1. Clinical and laboratory data of 64 patients with primary hyperparathyroidism from one institution

\begin{tabular}{|c|c|c|c|c|c|}
\hline Baseline & Asymptomatic & $\begin{array}{l}\text { Renal stone } \\
\text { disease }\end{array}$ & $\begin{array}{c}\text { Osteitis fibrosa } \\
\text { cystica }\end{array}$ & $\mathbf{P}$ & $\begin{array}{l}\text { Reference } \\
\text { Range }\end{array}$ \\
\hline Age (y) & $66.75 \pm 0.63$ & $55.8 \pm 5.09$ & $38.7 \pm 4.38$ & $<0.01$ & \\
\hline Sex ratio (M:F) & $1: 4$ & $2: 7$ & $11: 10$ & $<0.01$ & \\
\hline Serum calcium (mg/dL) & $10.98 \pm 0.02$ & $11.32 \pm 0.17$ & $13.35 \pm 0.35$ & $<0.01$ & $8.6-10.3$ \\
\hline Serum phosphorus (mg/dL) & $2.79 \pm 0.29$ & $2.56 \pm 0.47$ & $1.99 \pm 0.29$ & $<0.01$ & $2.5-4.5$ \\
\hline Serum PTH (pg/mL) & $135.45 \pm 13.50$ & $165.85 \pm 15.06$ & $579.6 \pm 628.4$ & $<0.01$ & $10-65$ \\
\hline Serum 25-hydroxyvitamin D (ng/mL) & $26.97 \pm 4.13$ & $20.02 \pm 0.56$ & $15.91 \pm 1.11$ & $<0.01$ & $12-68$ \\
\hline Urine NTx (nmol/mmol of creatinine) & $51.3 \pm 6.4$ & $154.1 \pm 62.9$ & $501.5 \pm 201$ & $<0.05$ & $\begin{array}{c}50-60 \text { (premenopausal) } \\
15-120 \text { (postmenopausal) } \\
6-65 \text { (men) }\end{array}$ \\
\hline Serum CTx (pg/mL) & $752.6 \pm 496.3$ & $727.3 \pm 220.4$ & $2,210.2 \pm 375.4$ & $<0.05$ & $\begin{array}{c}\text { 50-450 (premenopausal) } \\
\text { 90-680 (potsmenopausal) } \\
70-480 \text { (men) }\end{array}$ \\
\hline \multicolumn{6}{|l|}{ BMD t score } \\
\hline Lumbar spine & $-2.02 \pm 0.15$ & $-1.83 \pm 0.85$ & $-4.25 \pm 0.24$ & $<0.01$ & \\
\hline Femoral neck & $-2.03 \pm 0.28$ & $-1.81 \pm 0.38$ & $-5.44 \pm 1.37$ & $<0.01$ & \\
\hline Distal radius & $-2.23 \pm 0.74$ & $-1.79 \pm 0.04$ & $-5.33 \pm 0.69$ & $<0.01$ & \\
\hline
\end{tabular}

Adapted from: Bandeira and cols. (9).

The use of sestamibi scintigraphy in the preoperative localization of parathyroid lesions has improved the success of surgery, especially in patients who have had previous neck surgery. Success is dependent, in part, on successful localization of abnormal parathyroid tissue. This test can also be performed in suspected skeletal brown tumors and metastatic parathyroid cancer, which may be due to increased perfusion, metabolism and osteoclastic activity (9). In contrast to ultrasound and scintigraphy, 4D computed tomography can visualize, at times with greater accuracy, multiple gland involvement (8). Magnetic resonance imaging (MRI) may also be used especially to identify ectopic parathyroid tissue (11). Considering all options, SPECT-CT is often considered to be the first choice because of its better spatial resolution. The combination of two different methods can also be used to improve the localization of the parathyroid lesion (11).

\section{The hungry bone syndrome}

The "hungry bone disease" occurs in consequence of the rapid accrual of calcium from the intravascular compartment into the skeleton and under these conditions can result in severe hypocalcemia and the urgent need for intravenous calcium replacement $(1,2,7,8)$.
As parathyroidectomy is the treatment of choice for all patients with symptomatic PHPT, various degrees of improvement have been shown following surgical cure.

In severe disease, these include regression of skeletal abnormalities with increased bone mineral density and in many cases shrinkage of osteoclastomas $(1,8,12)$. In patients with OFC, the average gain in bone density after surgical cure was $40 \pm 29 \%$ in lumbar spine, 86 $\pm 39 \%$ in femoral neck and $22 \pm 11 \%$ in distal radial, only 1 year after surgery (7). The marked and rapid improvement in bone mineral density among subjects with OFC contrasts with the slower gains in those with asymptomatic PHPT $(1,13)$.

In severe PHPT, markedly increase bone turnover results in the efflux of calcium from bone. After parathyroidectomy, rapid bone resorption ceases immediately, but bone formation continues (14-17).

Bisphosphonates, described in the table 2, have been used preoperatively in patients with severe PHPT in order to decrease bone turnover (bone resorption and bone formation) and to prevent, therefore, the development of postoperatively severe hypocalcemia and its complications such as seizures and coma $(1,7,16)$.

A study that evaluated bisphosphonate use pre-operatively in patients with OFC (7) showed that the speed and degree of postoperative hypocalcemia was significantly controlled preventing the occurrence of specific 
Table 2. Suggested bisphosphonate regimen for pre-operative use in patients with osteitis fibrosa cystica

\begin{tabular}{lcccc}
\hline Compound & Route & Dose $\mathbf{( m g )}$ & Duration & Time before surgery \\
\hline Pamidronate & Intravenously & 90 & Single infusion & $10-30$ days \\
Zolendronic acid & Intravenously & 5 & Single infusion & $10-30$ days \\
\hline
\end{tabular}

signs and symptoms. Average serum calcium levels preoperatively were $13.51 \pm 0.87 \mathrm{mg} / \mathrm{dL}$ and PTH: 1389 $\pm 609 \mathrm{pg} / \mathrm{mL}$. In the first week following surgical cure, serum calcium and PTH levels fell to $8.23 \pm 0.46 \mathrm{mg} /$ $\mathrm{dL}$ and $45.8 \pm 72.9$ respectively. Oral calcium carbonate and vitamin D3 were sufficient, without the need for intravenous calcium administration (7) (Figures 4 and 5). The preoperative use of bisphosphonates did not appear to compromise the recovery of bone density after parathyroidectomy. Mean increases after 1 year of $40 \pm$ $29 \%$ in lumbar spine, $86 \pm 39 \%$ in femoral neck and 22 $\pm 11 \%$ in distal radius were appreciated (7) (Figure 6).

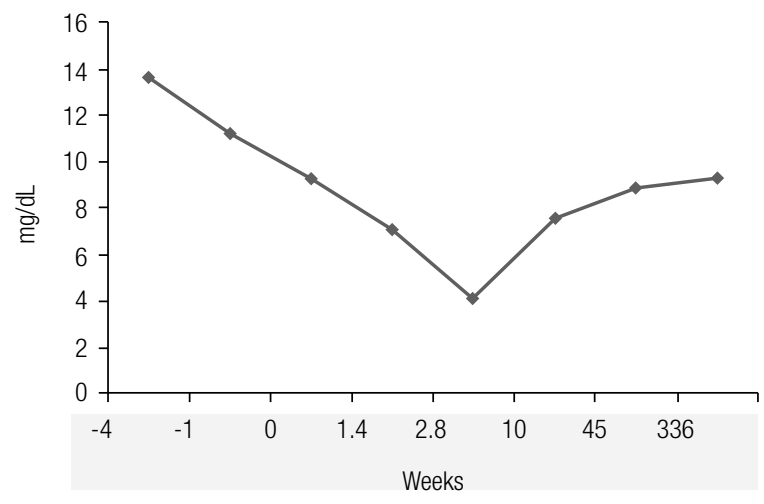

-4: before the bisphosphonate; -1: after bisphosphanate; 3: 0: time of parathyroidectomy.

Figure 4. Changes in serum calcium in a patient with severe PHPT who underwent treatment with alendronate $140 \mathrm{mg} /$ week for 6 weeks prior to parathyroidectomy.

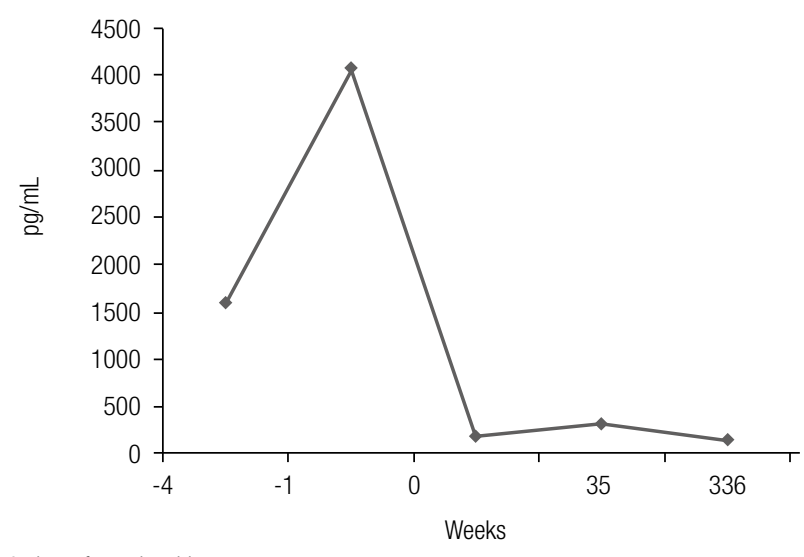

0 : time of parathyroidectomy.

Figure 5. Changes in serum PTH in the same patient of figure 2, showing sharp decrease immediately after parathyroidectomy.

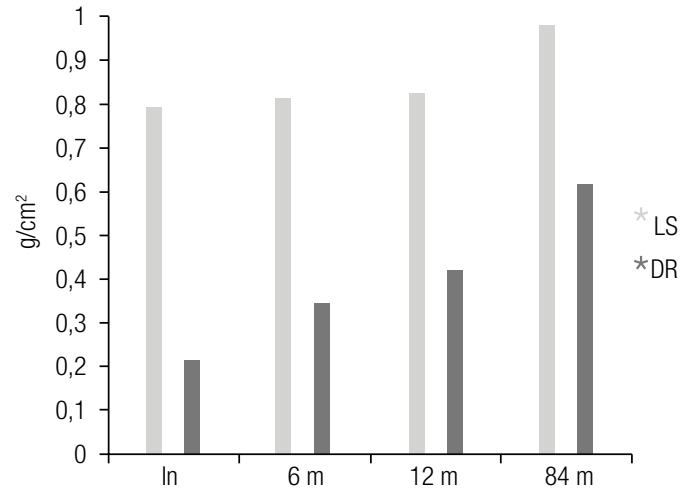

Figure 6. Long-term changes in bone mineral density in the same patient. Note the continuous gain in bone density up to seven years of follow-up.

Vitamin D deficiency is a risk factor for the development of hungry bone syndrome, and high-dose supplementation is recommended early postoperatively $(14,17)$. Although most patients respond to high dose cholicalciferol, some patients will need active metabolites of vitamin D such calcitriol (18).

In hungry bone syndrome, there is not a uniform standard therapeutic approach. Often, however, replacement amounts of calcium can be in the range of 6-12 $\mathrm{g}$ per day. The amount needed will vary according to the severity of hypocalcemia. Attention should be paid to the need for correction of hypomagnesemia also (15).

\section{SKELETAL DISEASE IN ASYMPTOMATIC AND IN NORMOCALCEMIC PRIMARY HYPERPARATHYROIDISM}

The preceding section reviews aspects of symptomatic primary hyperparathyroidism, a classical presentation that has become more and more uncommon. Over the past 40 years, with the widespread use of the multichannel autoanalyzer in the United States and elsewhere in the world, the presentation of PHPT has shifted to a predominantly asymptomatic one (19). Overt skeletal disease, detected radiologically, occurs in a vanishingly small percentage of patients. The early clinical presentation of PHPT undoubtedly accounts, at least in part, for the observation that overt skeletal disease has become unusual. Despite the fact that most patients do 
not show classical radiological findings of PHPT, bone involvement is readily detected in most patients by dual energy X-ray absorptiometry (DXA). By DXA, bone mineral density is typically reduced. More recently, application of newer imaging modalities such as the trabecular bone score (TBS) and high resolution peripheral quantitative computed tomography (HRpQCT), have demonstrated abnormalities in trabecular microarchitecture that are readily seen in the mild asymptomatic PHPT seen today in many parts of the world.

More recently, a newer presentation of PHPT has emerged, in which patients present with elevated PTH levels and consistently normal serum calcium. Patients with this phenotypical presentation, normocalcemic PHPT, are usually discovered during the evaluation for a metabolic bone disease. In this section we review the assessment of bone disease in mild asymptomatic and normocalcemic PHPT.

\section{Skeletal abnormalities in asymptomatic PHPT}

Most patients with PHPT in the developed, and now also in the developing world, are discovered to have hypercalcemia incidentally on routine blood tests. While X-rays rarely show classical findings of PHPT (see prior section), bone mass is typically reduced when it is measured by DXA. For many years, it was believed that the negative effects of PHPT on the skeleton were restricted to cortical bone. The densitometric profile of PHPT shows bone mineral density (BMD) reductions at the distal $1 / 3$ forearm, a site composed primarily of cortical bone, with relative preservation of the lumbar spine, a predominantly trabecular site $(13,19,20)$. Histomorphometric and micro-computed tomography analyses of bone biopsy specimens confirmed reductions in cortical bone, demonstrating that cortical thickness was significantly lower in patients with PHPT compared to controls, with relative preservation of trabecular parameters (20-22).

While the densitometric and histomorphometric findings are generally in agreement, they are inconsistent with numerous epidemiological reports demonstrating increased fracture risk at both vertebral and non-vertebral sites in patients with PHPT (23-27). Newer technologies, such as HRpQCT, have provided further understanding of the microstructural skeletal features in PHPT. Data from these newer technologies are more consistent with epidemiological fracture data in PHPT. HRpQCT measures volumetric bone density, bone ge- ometry, skeletal microarchitecture, and bone strength in the cortical and trabecular compartments. By HRpQCT, both the cortical and trabecular compartments are affected adversely in PHPT, with reduced volumetric densities at cortical and trabecular compartments, thinner cortices, and more widely spaced and heterogeneously distributed trabeculae (28-30). These studies have also shown that the adverse effects of PHPT are likely to be mitigated by weight-bearing, since the radius, a non weight-bearing site, is generally more affected than the tibia, a weight-bearing site. Stein and cols. (29) have provided additional insight into trabecular microstructure by using individual trabecula segmentation analysis of the HRpQCT images, a technique to segment the trabecular network into individual plates and rods. By this analysis in postmenopausal women with PHPT, the trabecular network is topologically configured with relatively fewer plate-like than rod-like trabeculae, reduced connectivity, and a less well axially aligned trabecular network. This analysis is consistent with the expectation that trabecular bone strength is reduced in PHPT.

Although HRpQCT remains a research tool, a new technology, recently approved for clinical use in the United States and Europe, is likely to become more widely available because it is an adaptation of the lumbar spine DXA image. Trabecular bone score (TBS) is a gray-level textural analysis that provides an indirect index of trabecular microarchitecture. TBS is obtained from the DXA image through the application of TBS software (31-33). A high TBS value is associated with a dense trabecular network and greater bone strength, whereas a low TBS value is associated with qualitatively worse bone microarchitecture $(32,33)$. Prospective studies in postmenopausal women have demonstrated that TBS predicts vertebral, hip and other major osteoporotic fractures (34-37). In PHPT, TBS shows a partially degraded microarchitecture (38-40) including cohorts that are predominantly asymptomatic with mild disease. In a predominantly asymptomatic cohort, Silva and cols. (38) demonstrated that while over half of the subjects presented with normal lumbar spine T-scores by DXA, only $27 \%$ of subjects had normal TBS values. TBS has also been found to be associated with vertebral fracture in subjects with PHPT $(39,40)$.

\section{Natural history of bone loss in asymptomatic PHPT}

The natural history of asymptomatic PHPT was defined by two large prospective cohorts. Rao and cols. 
$(41,42)$ monitored 80 asymptomatic patients for up to 11 years, during which time there was no worsening of biochemical or densitometric indices. Silverberg and cols. (19) published their cohort of 101 asymptomatic patients followed for up to 10 years. Approximately $25 \%$ of these patients showed disease progression. Age was the only predictor of progression, with patients younger than 50 years of age three times more likely to show progression. Rubin and cols. (13) reported the 15-year follow-up study of these patients, finding that disease progression over that longer time period amounted to $37 \%$ of the cohort. Of particular interest was accelerated bone loss at the distal $1 / 3$ radius and femoral neck between years 10 and 15 . There are limited data on the natural history of PHPT using the new technologies described above. In a small cohort study by Eller-Vainicher and cols. (40) TBS remained stable in a non-operative cohort followed over 2 years. There are no published longitudinal HRpQCT data in subjects with PHPT not undergoing parathyroidectomy.

\section{Reversal of abnormalities post-parathyroidectomy}

In the cohort studied by the group at Columbia University Medical Center (13), patients who underwent successful parathyroid surgery experienced gains in bone density by DXA at 5,10 , and 15 years, respectively, of 9,6 , and $12 \%$ at the lumbar spine; 1,7 and $10 \%$ at the femoral neck; and 4,8 , and $7 \%$ at the distal radius. The findings have been confirmed by randomized control trials of surgery versus observation (42-44) also demonstrating increased bone density at the hip and/ or lumbar spine.

In the study of Eller-Vainicher and cols. (40) TBS was compared in a small cohort of subjects with PHPT undergoing parathyroidectomy to a non-operative cohort. While TBS remained stable in the non-operative group, it improved in surgically-treated patients at month 24. While similar data were observed for BMD at lumbar spine and hip sites, the mean $\mathrm{Z}$-score increase for TBS was greater than for BMD at the lumbar spine or hip sites.

Hansen and cols. (45) prospectively followed women with PHPT before and 1 year post-parathyroidectomy using DXA and HRpQCT. By DXA, post-operative improvements in BMD were noted at the lumbar spine and total hip. By HRpQCT, at both the radius and tibia, there were significant improvements in various cortical and trabecular parameters, associated with significant changes in bone biomechanical properties. These changes were associated with an improvement in failure load.

\section{Normocalcemic PHPT}

Over the past decade, a newer clinical description of PHPT has emerged, characterized by consistently normal total and ionized serum calcium concentrations with elevated PTH levels, in the absence of obvious causes for secondary hyperparathyroidism $(41,46-48)$. Individuals with this new phenotype, normocalcemic PHPT, are increasingly being discovered as many physicians are now requesting PTH levels in patients with, or suspected of, an underlying metabolic bone disease despite a normal serum calcium concentration (46-48). As a consequence, normocalcemic PHPT has primarily been diagnosed in populations referred to metabolic bone diseases units. One might expect, therefore, that these subjects are not truly asymptomatic because they constitute a referral population. For example, in a cohort described by Lowe and cols. (49) at the time of diagnosis, $57 \%$ had osteoporosis, $11 \%$ had documented fragility fractures, and $14 \%$ had nephrolithiasis. Other normocalcemic cohorts have been published (50-54), also describing patients from referral populations. While bone disease in these normocalcemic subjects has been noted, in some studies but not in others (51), to be more severe, as determined by DXA, than in subjects with asymptomatic hypercalcemic PHPT, this is likely to be a function of selection bias.

Charopoulos and cols. (55) utilized peripheral quantitative computed tomography to assess the skeleton in subjects with normocalcemic PHPT in comparison to those with hypercalcemic disease. The investigators found catabolic effects in both groups that were more pronounced in hypercalcemic subjects. However, while cortical geometric properties were also adversely affected in subjects with normocalcemic PHPT, trabecular properties were preserved.

The natural history of skeletal disease in normocalcemic PHPT is not well defined, nor is the response to parathyroidectomy. In the cohort described by Lowe and cols. (49) during a mean follow-up period of 3.1 years, $43 \%$ of patients had a decline in bone density of at least $5 \%$ by DXA, with similar reductions at all sites. In a cohort described by Koumakis and cols. (54), subjects with normal total and ionized calcium levels pre-operatively demonstrated a densitometric gain of $4.1 \%$ at the femoral neck at 1 year after parathyroid surgery $(\mathrm{p}=0.044)$, without significant change at the spine or radius. 


\section{CONCLUSIONS}

The classical descriptions of PHPT are of a highly symptomatic disease with overt skeletal manifestations, including osteitis fibrosis cystica. While uncommon, patients still present with this severe form of PHPT even in countries where multichannel screening is routine. In countries where screening tests are not routine, overt skeletal disease is more common. While the presentation of PHPT has shifted to an asymptomatic one, new technologies such as TBS and HRpQCT have documented more extensive skeletal involvement in asymptomatic PHPT than previously appreciated. Further studies are needed to delineate the skeletal involvement in normocalcemic PHPT. In addition, the extent to which subjects show improvement after successful parathyroid surgery, as determined by these more sensitive approaches to skeletal assessment, is needed.

Funding source: this work was supported in part by National Institutes of Health grants DK32333 and DK095944.

Disclosures: Dr. Bandeira is a consultant for Servier and Sanofi and receives research support from Amgen. Dr. Bilezikian is a consultant for Amgen, Eli Lilly, Radius, NPS Pharmaceuticals, Merck, and GSK, and receives research support from NPS Pharmaceuticals and Amgen. Drs. Silva, Cusano, Cassibba, Almeida and Machado: no conflicts of interest reported.

\section{REFERENCES}

1. Bandeira F, Griz L, Caldas G, Bandeira C, Freese E. From mild to severe primary hyperparathyroidism: the Brazilian experience. Arq Bras Endocrinol Metabol. 2006;50(4):657-63.

2. Kulak CA, Bandeira C, Voss D, Sobieszczyk SM, Silverberg SJ, Bandeira $F$, et al. Marked improvement in bone mass after parathyroidectomy in osteitis fibrosa cystica. J Clin Endocrinol Metab 1998;83(3):732-5.

3. Silverberg SJ, Clarke B, Peacock M, et al. Current issues in the presentation of asymptomatic primary hyperparathyroidism: proceedings of the fourth international workshop. J Clin Endocrinol Metabol. 2014; [In press].

4. Zhao L, Liu JM, He XY, Zhao HY, Sun LH, Tao B, et al. The changing clinical patterns of primary hyperparathyroidism in Chinese patients: data from 2000 to 2010 in a single clinical center. J Clin Endocrinol Metab. 2013;98(2):721-8.

5. Oliveira UE, Ohe MN, Santos RO, Cervantes O, Abrahão M, Lazaretti-Castro $\mathrm{M}$, et al. Analysis of the diagnostic presentation profile, parathyroidectomy indication and bone mineral density follow-up of Brazilian patients with primary hyperparathyroidism. Braz J Med Biol Res. 2007;40(4):519-26.

6. Eufrazino $C$, Veras A, Bandeira F. epidemiology of primary hyperparathyroidism and its non-classical manifestations in the city of Recife, Brazil. Clin Med Insights Endocrinol Diabetes. 2013;6:69-74.

7. França TC, Griz L, Pinho J, Diniz ET, Andrade LD, Lucena CS, et al. Bisphosphonates can reduce bone hunger after parathyroidectomy in patients with primary hyperparathyroidism and osteitis fibrosa cystica. Rev Bras Reumatol. 2011;51(2):131-7.
8. Bandeira F, Griz L, Chaves N, Carvalho NC, Borges LM, LazarettiCastro $M$, et al. Diagnosis and management of primary hyperparathyroidism--a scientific statement from the Department of Bone Metabolism, the Brazilian Society for Endocrinology and Metabolism. Arq Bras Endocrinol Metabol. 2013;57(6):406-24.

9. Bandeira FA, Oliveira RI, Griz LH, Caldas G, Bandeira C. Differences in accuracy of $99 \mathrm{mTc}$-sestamibi scanning between severe and mild forms of primary hyperparathyroidism. $\mathrm{J}$ Nucl Med Technol. 2008;36(1):30-5.

10. Bilezikian JP, Brandi ML, Eastell R, et al. Guidelines for the management of asymptomatic primary hyperparathyroidism: summary statement from the fourth international workshop. J Clin Endocrinol Metab 2014; [In press].

11. Udelsman R, Akerström G, Biagini $C$, et al. The surgical management of asymptomatic primary hyperparathyroidism: proceedings of the fourth international workshop. J Clin Endocrinol Metab. 2014; [In press].

12. Silverberg SJ, Gartenberg F, Jacobs TP, Shane E, Siris E, Staron $\mathrm{RB}$, et al. Increased bone mineral density after parathyroidectomy in primary hyperparathyroidism. J Clin Endocrinol Metab. 1995;80(3):729-34.

13. Rubin MR, Bilezikian JP, McMahon DJ, Jacobs T, Shane E, Siris $E$, et al. The natural history of primary hyperparathyroidism with or without parathyroid surgery after 15 years. J Clin Endocrinol Metab. 2008;93(9):3462-70.

14. Brasier AR, Nussbaum SR. Hungry bone syndrome: clinical and biochemical predictors of its occurrence after parathyroid surgery. Am J Med. 1988;84(4):654-60.

15. Witteveen JE, van Thiel S, Romijn JA, Hamdy NA. Hungry bone syndrome: still a challenge in the post-operative management of primary hyperparathyroidism: a systematic review of the literature. Eur J Endocrinol. 2013;168(3):R45-53.

16. Bandeira $F$, Amaral $L$, Aragão P. Primary hyperparathyroidism. In: Bandeira F, Gharib H, Golbert A, Griz L, Faria M, eds. Endocrinology and diabetes: a problem-oriented approach. New York: Springer; 2013. p. 279-91.

17. Graal MB, Wolffenbuttel BH. Consequences of long-term hyperparathyroidism. Neth J Med. 1998;53(1):37-42.

18. Boyle IT, Fogelman I, Boyce B, Thomson JE, Beastall GH, Mclntosh WB, et al. 1alpha-hydroxyvitamin D3 in primary hyperparathyroidism. Clin Endocrinol (Oxf). 1977;7Suppl:215s-22s.

19. Silverberg SJ, Shane E, Jacobs TP, Siris E, Bilezikian JP. A 10-year prospective study of primary hyperparathyroidism with or without parathyroid surgery. N Engl J Med. 1999;341(17):1249-55.

20. Silverberg SJ, Shane E, de la Cruz L, Dempster DW, Feldman F, Seldin D, et al. Skeletal disease in primary hyperparathyroidism. J Bone Miner Res. 1989;4(3):283-91.

21. Parisien $M$, Silverberg $S J$, Shane $E$, de la Cruz L, Lindsay $R$, Bilezikian JP, et al. The histomorphometry of bone in primary hyperparathyroidism: preservation of cancellous bone structure. $\mathrm{J}$ Clin Endocrinol Metab. 1990;70(4):930-8.

22. Dempster DW, Muller R, Zhou H, Kohler T, Shane E, Parisien M, et al. Preserved three-dimensional cancellous bone structure in mild primary hyperparathyroidism. Bone. 2007;41(1):19-24.

23. Khosla S, Melton LJ, III, Wermers RA, Crowson CS, O'Fallon WM, Riggs BL. Primary hyperparathyroidism and the risk of fracture: a population-based study. J Bone Miner Res. 1999;14(10):1700-7.

24. Vestergaard $P$, Mollerup $C L$, Frokjaer VG, Christiansen $P, B l i-$ chert-Toft M, Mosekilde L. Cohort study of risk of fracture before and after surgery for primary hyperparathyroidism. BMJ. 2000;321(7261):598-602.

25. Vestergaard $P$, Mosekilde L. Fractures in patients with primary hyperparathyroidism: nationwide follow-up study of 1201 patients. World J Surg. 2003;27(3):343-9. 
26. Vignali E, Viccica G, Diacinti D, Cetani F, Cianferotti L, Ambrogini $\mathrm{E}$, et al. Morphometric vertebral fractures in postmenopausal women with primary hyperparathyroidism. J Clin Endocrinol Metab. 2009;94(7):2306-12.

27. Yu N, Donnan PT, Flynn RW, Murphy MJ, Smith D, Rudman A, et al. Increased mortality and morbidity in mild primary hyperparathyroid patients. The Parathyroid Epidemiology and Audit Research Study (PEARS). Clin Endocrinol (Oxf). 2010;73(1):30-4.

28. Hansen S, Beck Jensen JE, Rasmussen L, Hauge EM, Brixen K. Effects on bone geometry, density, and microarchitecture in the distal radius but not the tibia in women with primary hyperparathyroidism: a case-control study using HR-pQCT. J Bone Miner Res. 2010;25(9):1941-7.

29. Stein EM, Silva BC, Boutroy S, Zhou B, Wang J, Udesky J, et al. Primary hyperparathyroidism is associated with abnormal cortical and trabecular microstructure and reduced bone stiffness in postmenopausal women. J Bone Miner Res. 2013;28(5):1029-40.

30. Vu TD, Wang XF, Wang $Q$, Cusano NE, Irani $D$, Silva BC, et al. New insights into the effects of primary hyperparathyroidism on the cortical and trabecular compartments of bone. Bone. 2013;55(1):57-63.

31. Silva BC, Leslie WD, Resch H, Lamy O, Lesnyak O, Binkley N, et al. Trabecular bone score: a noninvasive analytical method based upon the DXA image. J Bone Miner Res. 2014;29(3):518-30.

32. Hans D, Barthe N, Boutroy S, Pothuaud L, Winzenrieth R, Krieg MA. Correlations between trabecular bone score, measured using anteroposterior dual-energy $\mathrm{X}$-ray absorptiometry acquisition, and 3-dimensional parameters of bone microarchitecture: an experimental study on human cadaver vertebrae. J Clin Densitom. 2011;14(3):302-12.

33. Roux JP, Wegrzyn J, Boutroy S, Bouxsein ML, Hans D, Chapurlat $R$. The predictive value of trabecular bone score (TBS) on whole lumbar vertebrae mechanics: an ex vivo study. Osteoporos Int. 2013;24(9):2455-60.

34. Hans D, Goertzen AL, Krieg MA, Leslie WD. Bone microarchitecture assessed by TBS predicts osteoporotic fractures independent of bone density: the Manitoba study. J Bone Miner Res. 2011;26(11):2762-9.

35. Boutroy S, Hans D, Sornay-Rendu E, Vilayphiou N, Winzenrieth R, Chapurlat R. Trabecular bone score improves fracture risk prediction in non-osteoporotic women: the OFELY study. Osteoporos Int. 2013;24(1):77-85.

36. Briot K, Paternotte S, Kolta S, Eastell R, Reid DM, Felsenberg D, et al. Added value of trabecular bone score to bone mineral density for prediction of osteoporotic fractures in postmenopausal women:The OPUS study. Bone. 2013;57(1):232-6.

37. Iki M, Tamaki J, Kadowaki E, Sato $Y$, Dongmei $N$, Winzenrieth $R$, et al. Trabecular bone score (TBS) predicts vertebral fractures in Japanese women over 10 years independently of bone density and prevalent vertebral deformity: the Japanese PopulationBased Osteoporosis (JPOS) cohort study. J Bone Miner Res. 2014;29(2):399-407.

38. Silva BC, Boutroy S, Zhang C, McMahon DJ, Zhou B, Wang J, et al. Trabecular bone score (TBS)--a novel method to evaluate bone microarchitectural texture in patients with primary hyperparathyroidism. J Clin Endocrinol Metab. 2013;98(5):1963-70.

39. Romagnoli E, Cipriani C, Nofroni I, Castro C, Angelozzi M, Scarpiello A, et al. "Trabecular Bone Score" (TBS): an indirect measure of bone micro-architecture in postmenopausal patients with primary hyperparathyroidism. Bone. 2013;53(1):154-9.
40. Eller-Vainicher C, Filopanti M, Palmieri S, Ulivieri FM, Morelli V, Zhukouskaya VV, et al. Bone quality, as measured by trabecular bone score, in patients with primary hyperparathyroidism. Eur $\mathrm{J}$ Endocrinol. 2013;169(2):155-62.

41. Rao DS, Wilson RJ, Kleerekoper M, Parfitt AM. Lack of biochemical progression or continuation of accelerated bone loss in mild asymptomatic primary hyperparathyroidism: evidence for biphasic disease course. J Clin Endocrinol Metab. 1988;67(6):1294-8.

42. Rao DS, Phillips ER, Divine GW, Talpos GB. Randomized controlled clinical trial of surgery versus no surgery in patients with mild asymptomatic primary hyperparathyroidism. J Clin Endocrinol Metab. 2004;89(11):5415-22.

43. Bollerslev J, Jansson S, Mollerup CL, Nordenström J, Lundgren E, Tørring $\mathrm{O}$, et al. Medical observation, compared with parathyroidectomy, for asymptomatic primary hyperparathyroidism: a prospective, randomized trial. J Clin Endocrinol Metab. 2007;92(5):1687-92.

44. Ambrogini E, Cetani F, Cianferotti L, Vignali E, Banti C, Viccica G, et al. Surgery or surveillance for mild asymptomatic primary hyperparathyroidism: a prospective, randomized clinical trial. J Clin Endocrinol Metab. 2007;92(8):3114-21.

45. Hansen S, Hauge EM, Rasmussen L, Jensen JE, Brixen K. Parathyroidectomy improves bone geometry and microarchitecture in female patients with primary hyperparathyroidism: a oneyear prospective controlled study using high-resolution peripheral quantitative computed tomography. J Bone Miner Res. 2012;27(5):1150-8.

46. Maruani G, Hertig A, Paillard M, Houillier P. Normocalcemic primary hyperparathyroidism: evidence for a generalized target-tissue resistance to parathyroid hormone. J Clin Endocrinol Metab. 2003;88(10):4641-8.

47. Silverberg SJ, Bilezikian JP. "Incipient" primary hyperparathyroidism: a "forme fruste" of an old disease. J Clin Endocrinol Metab. 2003;88(11):5348-52.

48. Bilezikian JP, Silverberg SJ. Normocalcemic primary hyperparathyroidism. Arq Bras Endocrinol Metabol. 2010;54(2):106-9.

49. Lowe $H$, McMahon DJ, Rubin MR, Bilezikian JP, Silverberg SJ. Normocalcemic primary hyperparathyroidism: further characterization of a new clinical phenotype. J Clin Endocrinol Metab. 2007;92(8):3001-5.

50. Tordjman KM, Greenman Y, Osher E, Shenkerman G, Stern N. Characterization of normocalcemic primary hyperparathyroidism. Am J Med. 2004;117(11):861-3.

51. Amaral LM, Queiroz DC, Marques TF, Mendes M, Bandeira F. Normocalcemic versus hypercalcemic primary hyperparathyroidism: more stone than bone? J Osteoporos. 2012;2012:128352.

52. Cakir I, Unluhizarci K, Tanriverdi F, Elbuken G, Karaca Z, Kelestimur F. Investigation of insulin resistance in patients with normocalcemic primary hyperparathyroidism. Endocrine. 2012;42(2):419-22.

53. Wade TJ, Yen TW, Amin AL, Wang TS. Surgical management of normocalcemic primary hyperparathyroidism. World J Surg. 2012;36(4):761-6.

54. Koumakis E, Souberbielle JC, Sarfati E, Meunier M, Maury E, Gallimard $E$, et al. Bone mineral density evolution after successful parathyroidectomy in patients with normocalcemic primary hyperparathyroidism. J Clin Endocrinol Metab. 2013;98(8):3213-20.

55. Charopoulos I, Tournis S, Trovas G, Raptou P, Kaldrymides $P$, Skarandavos $G$, et al. Effect of primary hyperparathyroidism on volumetric bone mineral density and bone geometry assessed by peripheral quantitative computed tomography in postmenopausal women. J Clin Endocrinol Metab. 2006;91(5):1748-53. 